How to cite this article:

Duarte, M. (2012). Prostitution and Trafficking in Portugal: Legislation, Policy, and Claims.

Sexuality Research and Social Policy, 9, 258-268. https://doi.org/10.1007/s13178-012-0093-2

\title{
Prostitution and Trafficking in Portugal: Legislation, Policy, and Claims
}

\author{
Madalena Duarte
}

\begin{abstract}
This paper documents recent changes in legislation and policies surrounding prostitution in Portugal while discussing the role played by sexual trafficking in the way prostitution is framed, institutionally and socially, in the country. In Portuguese legislation, prostitution has not been a crime per se since 1982, but activities related to prostitution, including pimping and benefitting from the prostitution of others, are considered crimes. This legal inconsistency is further complicated by the lack of specific policies addressing the living and working conditions of sex workers. At the same time, growing concern about sex trafficking has resulted in a new set of policies that ultimately influence the regulation of prostitution, in particular the prostitution of immigrant women. This paper shows that these sextrafficking-related policies and practices have contributed to creating idealized types of "victims" and investigates the risks and consequences of this typology.
\end{abstract}

Keywords Prostitution - Sexual trafficking $\cdot$ Gender policies $\cdot$ Feminism $\cdot$ Immigrant women

\section{Introduction}

The sex trafficking of women has received growing interest from states, international bodies, nongovernmental organizations, the media, and academia since the mid-1980s (Outshoorn 2005). The greater visibility conferred to this phenomenon has translated, on a national and international level, into policies designed to combat and prevent it. However, the efficiency of these policies is debatable mainly

\section{Duarte $(\bowtie)$}

Center for Social Studies, University of Coimbra,

Colégio de São Jerónimo, Apartado 3087,

3001-401 Coimbra, Portugal

e-mail: madalena@ces.uc.pt because sex trafficking is far from being an isolated problem. Its causes are intrinsically linked to other social, economic, political, and cultural phenomena, meaning that in several cases, it does not just involve a violation of rights resulting from trafficking. In the specific case of the trafficking of women for the purposes of sexual exploitation, several authors argue that prostitution must be included in these policies, in particular in the legal-normative framework of each country. However, various interpretations about the desirable course of law coexist: while some opinions veer towards criminalizing prostitution (e.g., Barry 1995), others demand that prostitution be regulated as a form of employment (e.g., Kempadoo 2005). This range of interpretations contribute to the persistence of difficulties in various countries with regard to identifying victims of trafficking in the day-to-day work of the police, legal actors, and social workers among others (Skilbrei and Tveit 2008).

Portugal is an interesting case in this respect. In recent years, as a result of pressure from some nongovernmental organizations and the international context, Portugal has produced several legislative measures and policies targeting trafficking for the purposes of sexual exploitation. Portugal has signed and ratified the Protocol to Prevent, Suppress and Punish Trafficking in Persons, Especially Women and Children, often referred to as the Palermo Protocol. ${ }^{1}$ In Portugal, as in other countries, the protocol, and the definition of trafficking in it, is the starting point for defining and stemming trafficking. Still, while the Protocol tends to be unanimous in terms of definition, it does not assume any stance on the relationship between trafficking and prostitution nor does it clearly define the terms "sexual exploitation" and "prostitution." This lack of clarity in an international context goes hand in hand, in Portugal, with a lack of visibility of the prostitution issue in the public arena and, consequently,

$\overline{{ }^{1} \text { Approved and }}$ ratified by Portugal in 2004 
the debate on the regulation of prostitution has been delayed, unlike the one on sex trafficking which has achieved a considerable weight on the political agenda.

This paper will discuss the consequences of policy development in Portugal concerning legislation related to sex trafficking that fails to address prostitution, namely, when discussing the concept of sex trafficking, using findings from two qualitative studies: one on the trafficking of women for the purposes of sexual exploitation in Portugal and another on Brazilian women in prostitution in Portugal. As we shall see, since the predominant nationality in the female prostitution market in Portugal coincides with the one identified in the official data concerning victims of sex trafficking-Brazilian — the debate becomes even more intertwined.

\section{Trafficking and Exploitation: Debating the Formal Definitions}

Concerns over the trafficking of women began in the late nineteenth century and early twentieth century with anxieties over the migration of individual women and the capture and enslavement of women for prostitution. In the nineteenth century, the intensification of female migration as an independent and self-determined strategy soon created a certain fear of the immorality that might be introduced into Western countries, specifically due to the perception that women had migrated to work as prostitutes (Sullivan 2003). This led to a racially and sexually based panic that gave rise to the fear of white slave trafficking (Doezema 2005). This is not to deny the fact that women were effectively being trafficked or exploited, but rather to attempt to contextualize the discourse of trafficking and the emergence of policies to combat this, emerging out of a fear of the nonWestern, criminal, violent "other" who brutalized and violated them. These concerns led to the creation of the International Convention for the Suppression of Traffic in Persons and the Exploitation of the Prostitution of Others, approved by the General Assembly of the United Nations Resolution 317(IV) of 2 December 1949 and concluded at Lake Success in New York on 21 March $1950{ }^{2}$

It was in the 1980s that the feminist movement began to engage with the question of international trafficking and prostitution, although without reaching a consensus on the matter. On the one hand, there are the "abolitionist feminists" who consider that prostitution reduces women to objects to be purchased and is always a form of sexual exploitation. Barry (1995), one of the founders of the Coalition Against Trafficking in Women and one of the most active voices on this front, argues that sexual exploitation is

\footnotetext{
${ }^{2}$ Ratified in Portugal by Presidential Decree no. 48/91 of 10 October
}

a political condition and the basis of the subordination of and discrimination against women and the perpetuation of patriarchy. Jeffreys (1999, p. 180) believes that a woman's willingness to engage in prostitution is politically and socially constructed on the basis of poverty, sexual abuse, and women's family obligations. Those who support this position make no distinction between enforced and voluntary prostitution and consider that any concession by the state towards legalization is essentially a concession to constant violations of human rights, dignity, and sexual autonomy.

At the start of the 1990s, this position was the target of countless critiques, both by the transnational feminist movement and the sex workers movement. The latter does not see prostitution as an essentially degrading activity or as an instance of the extreme sexual oppression of women, but rather as an activity that reflects the right of women to control their own bodies, which includes providing sexual services. They therefore argue that prostitution is a job that should have a legally established framework so that the rights of sex workers, who are not necessarily only those who practice prostitution, can be respected. They believe that the relationship between trafficking and prostitution is often invoked to block the legalization of prostitution and the establishment of sex workers' rights (Lopes 2001).

The debate summarized here had implications on the drafting of the Palermo Protocol. As said before, the Palermo Protocol ${ }^{3}$ was a response to the need to create a definition of trafficking that could be widely agreed upon and could replace the Convention for the Suppression of Traffic in Persons and the Exploitation of the Prostitution of Others. During the negotiations for the protocol, it was quickly agreed that enforced prostitution came under the proposed definition of trafficking, but there was an intense discussion on whether prostitution in general should be included (Engle 2004, p. 58). Due to this diversity of legal situations, the protocol does not clarify this controversial issue but leaves it as a matter for individual states to decide.

This international legal void and the polarization of feminist debates on prostitution make the definition of trafficking harder to interpret. Because of the concept of vulnerability inscribed in the text of the protocol, "for some, women travelling across borders for prostitution with the aid of others will always be trafficking as prostitution is seen as something women can never enter into voluntarily" (Skilbrei and Tveit 2008, p. 14).

\footnotetext{
${ }^{3}$ The protocol states in Article 3 that trafficking is defined as "The recruitment, transportation, transfer, harboring or receipt of persons, by means of the threat or use of force or other forms of coercion, of abduction, of fraud, of deception, of the abuse of power or of a position of vulnerability or of the giving or receiving of payments or benefits to achieve the consent of a person having control over another person, for the purpose of exploitation."
} 
The critique to this view is voiced by authors such as Kempadoo and Doezema (1998), who have studied these questions from a Southern perspective. ${ }^{4}$ According to them, the risk is to create an image of the woman from the South as the eternal submissive, who is ignorant, bound by traditional cultural concepts and victimized, while Western women emerge as the civilized saviors. Moreover, they also discuss that those arguments make female migrants vulnerable to perceptions that women lack agency, reflected by the argument that women cannot enter prostitution voluntarily. These and other authors claim that with the establishment of neoliberal globalization from the 1980s onwards, we have been witnessing the increased vulnerability of millions of people throughout the world (Santos et al. 2010). This means that even in the richest country in the world, people are more vulnerable. In the current climate of unemployment and weakening of social rights, more and more people decide to emigrate in search of better social and economic conditions, even if they are aware of the risks they incur. As a consequence, in various countries, we are beginning to encounter forms of overexploitation of the labor force, which are dragging certain groups of people into nonhuman conditions. According to this perspective, the trafficking of women for the purposes of sexual exploitation must today be understood beyond the scope of slavery, since capitalism and neoliberalism added a new element to slavery: the fact that workers are free to sell their labor. So it is necessary to take into consideration that there are women who are forced to work as prostitutes (against their will) and also situations in which female prostitutes gave their consent but are forced to work under conditions which they cannot choose. Therefore, according to certain views, women should be free to sell their sexual availability as labor, even if they end up in a situation of exploitation (Agustín 2007). Within this context of overexploitation in the labor market, various authors (e.g., Ehrenreich and Hochschild 2002) argue that any policy designed to fight human trafficking must extend beyond criminalizing traffickers to reinforce the rights of immigrants and sex workers.

So these feminist authors (e.g., Agustins 2007) claim that consent is a central issue here, and women's voices, migration choices, and survival strategies should be taken into account. It is true that immigration was, for a long time, seen and perceived as involving work in the fields and factories, therefore a male immigration. As such, the history of migrations is history and not herstory (Engle 2004, p. 8). But the migrant woman, as Kapur suggests, is a "resistant Subject": "she situates herself as a resistant subject, challenging

\footnotetext{
${ }^{4}$ Southern perspective or Southern epistemology is viewed as the retrieval of knowledge and practices of social groups that, because of capitalism and colonialism, were subordinated, historically and sociologically transformed into objects or feedstock for dominant Western knowledge, which was considered the only valid one (see Santos 2008).
}

'patriarchal' control within the family and marriage as well as a subject who exercises economic choices and social mobility" (Kapur 2001, p. 880). It is true that these choices are influenced by experiences of violence, poverty, racism, and marginalization. However, this awareness is a first step "to resist attempts to see power as overwhelming and consuming the subject" (Scoular 2004, p. 352).

The main challenge in most Western countries is to incorporate this debate into their policies and legislation, and their main problem might be to distinguish a victim of trafficking from a migrant prostitute and grant the latter the same rights granted to the former.

\section{The Portuguese Context: the (Late) Emergence of Prostitution in the Public Agenda}

Portugal spent 48 years under a dictatorship - known as the Estado Novo - the longest in Western Europe, which had serious consequences on gender equality and the consolidation of feminism and women's rights. It was only with the revolution of 1974, and the subsequent consolidation of Portuguese democracy, that equality in all areas was constitutionally recognized and that sexuality and the self-determination of women were publicly discussed (Tavares 2011; Duarte 2004). Some issues related to sexual and reproductive rights were put off while other formal and legislative measures of equality were achieved, namely, in the areas of labor, employment, and violence against women (Santos 2010). With key struggles focusing on the decriminalization of abortion, the issue of prostitution was systematically postponed and was not seen as a major concern by Portuguese feminists. The issue would arise years later in Portugal, not as a priority in and of itself but as a consequence of a growing concern with the sexual trafficking of women.

Portuguese women who make their living through prostitution have not organized in order to demand rights and recognition. Therefore, their views on the types of regulation they aspire to or the most appropriate ways to support their rights are unknown. Given this absence of a concerted movement on the part of sex workers, combined with a lack of a clear prolegalization position by feminists, the supporters of abolitionism within women's groups have predominated and have received the greatest media coverage.

The greater visibility of sexual trafficking when compared to prostitution was also the result of the role played by the Portuguese state, which some researchers have described as state feminism ${ }^{5}$ or institutional feminism (Hernes

\footnotetext{
State feminism is the action of official mechanisms of equality intended to introduce the demands of women's groups into the state, whether to influence the political process in order to achieve results or with the goal of effecting concrete social change or both (McBride and Mazur 2008; Hernes 1987).
} 
1987). Compared to other Southern European countries, the Portuguese state was in the vanguard of the creation of institutional and symbolic support for women's issues in the early 1970s (Valiente 2007). The new constitution in 1976 provided the democratic, antidiscriminatory legal framework to combat inequality and was the result of earlier manifestations of "institutional feminism" in 1970 with the creation of the Working Group for the Definition of a Comprehensive National Women's Policy). This group, which was established during a profoundly antifeminist dictatorship, survived the 1974 Revolution, albeit under another name, and continues to this day under the name Commission for Citizenship and Gender Equality).

Although a thorough debate on this issue is beyond the scope of this paper, it suffices to say that the relationship between the state and Portuguese women's groups regarding the subject of prostitution has been complex. On the one hand, women's movements have not exerted sufficient pressure to include a reflection about the role of prostitution in gender equality policies and in political agendas, as can be seen by the total absence of the subject in the National Equality Plans. ${ }^{6}$ On the other hand, if the underlying assumption is that there can be a transformation on the part of both the state and women's movements, there are no guarantees that this is an even-handed transformation. This is due to the fact that, firstly, these organizations financially depend on state support and, secondly, that the subsidies tend to be attributed to those nongovernmental women's organizations whose aims follow the priorities defined by the government program and the commission itself (which in turn follow the European and international mainstream). In this context, prostitution tends to appear-when it appears at all - either as a form of violence against women or in association with sex trafficking. This situation has impacts on the political arena, namely, in the lack of official policies on prostitution aimed at women's empowerment and self-determination, rather than on a perspective of welfare and charity. Another consequence is that prostitution has been legally framed only in the Penal Code.

Nevertheless, echoing transnational feminist movements briefly described above, a new public stance began to be voiced in Portugal towards the end of the 1990s. Originating in the more politicized feminist movements, in secular support groups for prostitutes, and in the LGBT movement, this new voice calls for the regulation of prostitution as a professional

\footnotetext{
${ }^{6}$ The National Equality Plans seek to strengthen national policy in the field of gender equality, meeting the commitments made at both national and international levels. The first National Equality Plan was created in 1999. The second plan started in 2003 and ended in 2006. The third one-called National Plan for Equality, Citizenship and Gender-was in force from 2007 to 2010. The fourth plan, with the title National Plan for Equality-Citizenship, Gender and NonDiscrimination, started in2011 and will finish in 2013.
}

activity.' This objective, however, has not been accomplished yet nor has the subject been introduced in the political agenda.

\section{Prostitution and Human Trafficking in Portugal: Legislation and Policies}

In the late 1800 s and in the early 1900 s, female prostitution was a socially tolerated phenomenon, even legitimized by the authorities, when practiced in accordance to administrative regulations (Bastos 1997, p. 38). The first general regulation of prostitution, dating back to 1858 , required prostitutes to register with the police authorities or the civil governor's office. Prostitutes became invisible to those who need not have knowledge of their presence, but visible, traceable, and identifiable to the authorities so that they might easily exert control over them. The reasons presented for the regulation of prostitution were based on metaphors of contagion, corruption, and contamination of "the healthy" by the "diseased." Thus, we saw the construction of an ideology based on health, including moral and social health.

The confluence of the morally, politically, and medically based ideological perspectives, expressed by movements advocating social purity, created the notion of female prostitution as a threat of biological and moral contamination of the "honest" and "innocent" Portuguese. This social construction of prostitution in the public space led to several pieces of legislation over the years $(1945,1949)$. These can be regarded as preabolitionist and were mainly intended to express the moral disapproval of prostitution based on the construction of a new identity of "deviant" and a new status of "social dangerousness," whose fundamental features were impurity and contamination (Bastos 1997). Thus, the state was (and has been) able to successfully impose the notion of the stigma of prostitution on the Portuguese population, encouraging the construction of a middle class model of femininity based on the concept of respectability (Roberts 1996).

This new structure intended not only to eradicate prostitution but also to convert the "genuine" prostitutes through care and social rehabilitation. All women under suspicion of

\footnotetext{
${ }^{7}$ There are some movements that suggest that in the future, there may be a more organized movement, even if supported by a faction of the feminist or LGBT movement. It is the case of the public demonstrations on Labor Day which, over the last 3 years, have seen selforganized people working in the sex industry demanding social rights. A special mention also goes to the Rede sobre Trabalho Sexual (RTS) (Network on Sexual Work), created in 2011, which represents the majority of national organizations that intervene directly on behalf of sex workers. The RTS comprises a group of organizations and individuals who work with people in the sex industry. This network feels that sex work is multifaceted and the experiences of those working in this field are varied and cannot be reduced to abuse, trafficking, and sexual exploitation. The still recent network has little visibility in the public arena.
} 
being prostitutes were immediately arrested, and their names were put on file. Male clients would be forgiven and, in fact, conceived of as victims of female seduction.

This regulationist policy was maintained in Portugal until 1962, when the practice of prostitution was prohibited. ${ }^{8}$ The political context of the time had a significant role on this legal change. The political changes which occurred in the 1920s and 1930s marked the beginning of the dictatorship in Portugal (1926-1974), and the state gained both strength and severity, intensifying repressive measures against prostitution; moral and "decent" habits received protection. The consolidation of the sociopolitical project of the Estado Novo (New State) was reflected in female prostitution; efforts were made to keep prostitutes distant from public life (Guinote and Oliveira 1989). Nevertheless, prohibition did not reduce the practice of prostitution in Portugal; instead, it led to a worsening of prostitutes' conditions, as they became more vulnerable to physical aggression, theft, rape, and even blackmail by the police force (Oliveira 2004, p. 32).

During the 1970s, there was a decrease in sexual rights and women's rights in both public and private spaces. After the 1974 Revolution, a transformation of behaviors was expected not only in politics but also in the social and cultural spheres. Although it only applied for EC membership in 1977, Portugal seemed to have adequately responded to international trends regarding gender equality. It was as early as 1980 , for example, that Portugal ratified the Convention on the Elimination of all Forms of Discrimination against Women. However, topics related to sexuality continued to find little space for public discussion. This silence can partly be explained by the oppression of women and the general conservative attitudes which had dominated the country for decades as well as by the presence of the Catholic Church in all spheres of life, both public and private. Thus, it was only in 1982, 8 years after the implementation of democracy, that prostitution was decriminalized through the Penal Code (rocuring or "pimping" continued to be considered crimes, punishable by a prison sentence of between 6 months and 5 years. Nevertheless, it should also be noted that the reference made in this article to prostitution and to "acts contrary to decency or sexual morality" and their insertion into the Penal Code reflected a greater concern with protecting social values than with safeguarding prostitutes' individual interests. There have been transformations in this legal definition in recent years, due to the growing concern about human trafficking in women, more so than about the legal framework of prostitution per se.

In $1995,{ }^{9}$ a new law amended the Penal Code, introducing relevant changes in this area. One of the main changes

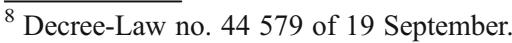

${ }^{9}$ Decree-Law no. $48 / 95$ of 15 March.
}

was that the protection of individual interests took priority over the protection of the moral values of society. This alteration in the philosophy of the law emerged from the outset in point 1 of the Preamble to the legislation, stating "the increasingly universal trend towards affirming human rights as a fundamental principle in modern societies, in addition to the reinforcement of the ethical dimension of the state, establishes justice as the first guarantor of the consolidation of the fundamental values recognized by the community, with a special emphasis on human dignity." The same goal of defending personal legal interests led the legislators to make changes to the system itself, namely, the removal of sex crimes from the chapter on crimes against the values and interests of society to the chapter on crimes against individuals, forming a separate chapter entitled "Crimes against liberty and sexual self-determination," and abandoning the moralistic concept ("general moral sentiments") in favor of liberty and sexual self-determination, eminently personal interests. It should be stressed, however, that the goal was not to punish the practice of prostitution itself, but the conduct of agents who, by deceptive or violent means, involved individuals in prostitution.

In $2007,{ }^{10}$ the last amendments relating to the trafficking of women for the purposes of sexual exploitation were introduced. Some of the amendments were imposed by European Union framework decisions and other instruments binding upon the Portuguese state. It should be noted, first of all, that the crime of human trafficking no longer appeared in the section of the Penal Code referring to crimes against sexual freedom but was moved to the chapter on crimes against personal freedom. Also, the crime of human trafficking does not contemplate only sexual trafficking, as it did before these changes, but also exploitation of labor and the extraction of organs. In accordance with the new law, individuals who "offer, deliver, entice, accept, transport, harbor or receive persons" for these purposes, either "by violence, kidnapping or extreme threats," "deception or fraudulent acts," or "by abusing the authority resulting from a hierarchical, economic, employment or family relationship in which the victim is a dependent" will be punished.

There were also changes regarding pimping. The new ${ }_{\text {law }}{ }^{11}$ states that an agent who, professionally or with intentions to seek profit, encourages, promotes, or facilities the engagement of another in prostitution shall be punished with a term of imprisonment of 6 months to 5 years. An agent who commits the crime of pimping, either by using violence or extreme threats, deception, or fraudulent acts; by abusing the authority resulting from a family, supervisory or guardian relationship, a dependent hierarchical, economic, or employment relationship; or by taking advantage of the

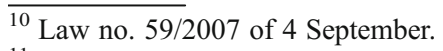

${ }^{11}$ Law no. 59/2007 of 4 September.
} 
psychological incapacity or any vulnerability associated with the victim, shall be punished with a term of imprisonment of 1 to 8 years.

In what concerns Immigration Law, in 2007 some amendments were also made, namely regarding human trafficking. The law of immigration considers that smuggling and human trafficking are unacceptable violations of human rights, placing the victim in a strict protection by the State. In pursuing this objective this Law provides for an increase of the penalty of the crime of aiding illegal immigration, with punishment of imprisonment of 2 to 8 years for agents carrying or maintaining a foreign citizen in inhumane conditions, risking his/her live or causing him/her physical harm or death.

A major legislative innovation concerns the forecast of a special regime for the residence permit to victims of human trafficking or smuggling. Despite this, residence, temporary stay, and short duration visas are only granted to nationals of third countries that have the means of subsistence, as a contract of employment. Otherwise, they only have authorization to a tourist visa for 3 months.

\section{Emergences and Absences: Impacts of the Law in Practice}

Societies are the image they have of themselves, reflected in the mirrors they construct to reproduce dominant identifications at any given time in history (Santos 1995). One of these mirrors is undoubtedly the law-i.e., laws, norms, and legal and judicial institutions - which not only reflects society but also guarantees that it functions. That is how we noted an evolution in the law regarding prostitution, since its criminalization, to the removal of sex crimes from the chapter on crimes against the values and interests of society to the chapter on crimes against individuals. Yet these mirrors do not just refer to the drafting of the law but also to its enforcement.

In this paper, I base our discussion on two studies carried out between 2006 and 2011, in Portugal: "Trafficking of Women in Portugal for Purposes of Sexual Exploitation" (Santos et al. 2008) and "Brazilian women in the Iberian connection: a comparative study on irregular migration and trafficking"12 (Leal et al. 2011). The first study aimed to characterize the reality of sex trafficking in Portugal and assess the enforcement of existing laws. The focus of the second study was to gather life stories of immigrant Brazilian women in Portugal and Spain who work as prostitutes. In both studies, a total of around 90 in-depth qualitative

\footnotetext{
$\overline{12}$ The original title is "Mulheres brasileiras na conexão ibérica: um estudo comparado entre migração irregular e tráfico." The Portuguese case was conducted by Madalena Duarte.
}

interviews were conducted with sex workers, ${ }^{1 J}$ police officers, border control officials, judges, public prosecutors, and NGO staff. In the first study, legal proceedings were also analyzed.

The empirical findings of these studies provided evidence that there are, both in the legislation relating to trafficking and prostitution and in its application, stereotypes and preconceptions that merit consideration. These biased views influenced not only the enforcement of the law but also the identification of victims of trafficking and are the result of a tenuous distinction between what is a voluntary migratory decision and a situation of coercion.

The following sections offer a brief discussion on some of the risks that arise from a growing production of social and legislative policy on sexual trafficking without the necessary reflection and debate on the issue of prostitution.

Sex Trafficking and Prostitution: the Key Issue of Consent

As with other violent scenarios, it may be said that idealized types of "victims" are found in sex trafficking. In the studies conducted, I encountered cases, either reported by interviewees or through analyses of legal proceedings, in which women did not know that the work awaiting them in Portugal was prostitution. However, in the interviews carried out with legal agents and NGO staff, most indicated the prevalence in Portugal of women who gave their initial consent to work in prostitution and later found themselves in situations in which they were exploited and their autonomy was severely restricted.

As in the work of Kelly and Regan (cited in Aronowitz 2001 , p. 166), there are in the narratives of our interviewees (police officers, border control officials, judges, and public prosecutors) several levels of victimization which correspond to different types of victims. The first level is associated with total coercion, in which victims are kidnapped and there is no consent whatsoever. Even though I did not find this type of case in the legal proceedings, they are cited by some of the interviewees as being the most serious. The second level refers to women deceived by promises of work that did not involve prostitution; in these cases, the women's consent was given on the basis of deceit. The third level involves a lesser degree of deception, when women know they will be working in the sex industry, but not in prostitution. Finally, the fourth level of victimization, which is taken to be the least serious, concerns women who, prior to departure, already knew that they would be working as prostitutes but did not know the extent to which they would be controlled, intimidated, indebted, and exploited:

The woman, from the moment she loses some values, her goal is to earn money. She spends 5 minutes in bed with one and then moves on to another. For this type

\footnotetext{
${ }^{13}$ The respondents were recruited though shelters and state authorities/ institutions (e.g., border control officials).
} 
of people perhaps this is not significant. Now, an individual who works on a farm, 24-hours a day of physical labor seems extremely violent to me. Because there are women who actually enjoy this type of life they lead. They lose their values and have no problem performing this work and do not even want to leave it. I do not see a person who works hard for 24 hours and wants to remain in that situation ad eternum. (Interview with police officer, 2010)

These different situations deserve careful consideration and reflection since, in addition to the paradigmatic "type" of sexual trafficking - the situation in which a woman has clearly been deceived and is forced to work as a prostitute for the first time against her will, through the use of coercion and force upon arrival in Portugal - I found a range of situations which represent striking forms of abuse and destruction. I suggest there are three main reasons why these cases run the risk of going unnoticed.

Firstly, there are many women who were prostitutes in their country of origin, and therefore, biased analyses tend to overlook them as victims or as victims of exploitation. Secondly, there are women who knew they were coming to work as prostitutes and accepted the initial rules of the game yet, despite maintaining the illusion that they live in a world they have created of their own free will, are frequently subject to redefinitions and changes of the rules by those in a position to take advantage of the previously mentioned vulnerabilities and invisibilities.

Finally, there are many immigrant women who chose to work as prostitutes in Portugal without losing control of the rules of the game. This fact per se, since it may correspond to the most visible face (and even the most common face of the phenomenon), may lead to a "sociological camouflaging" of situations in which women are victims of a dramatic reversal of the idea of sexual self-determination. The boundaries between these situations are subtle, since they may involve various forms of precariousness, creating a web from which women can easily fall into situations of sexual exploitation.

According to the interviewees to legal actors, the law is not sufficiently clear in the distinction between these different situations. Concepts inscribed in the text of the 2007 law, such as "vulnerability of the victim" may give rise to certain practical difficulties in identifying potential situations of sexual trafficking. The "elasticity" and scope of this concept lead to the assumption, for example, that almost all situations leading to prostitution are linked to extreme poverty. Examining the Portuguese law, some authors (e.g., Vaz Patto 2007) point out that the question of consent assumes particular relevance here, especially for those who are on opposite sides of the debate concerning the legalization of prostitution. The fact that consent is considered irrelevant in situations in which vulnerability is exploited may, in practice, come close to view that all prostitution is forced. But the reverse is equally possible, if consent is perceived as relevant, as the previous quote from a police officer illustrates.

According to the interviews with sex workers, several aspects need to be considered. Firstly, there is despair at their poverty in the country of origin - extreme situations of economic vulnerability and the inequalities between North and South tempt women into emigrating on the basis of vague proposals, leading them into situations of total ontological uncertainty which are forged and exploited by the "sex industry." Secondly, there is the fact that prostitution is a phenomenon that takes place within the shadows of society, based on concealment and criminality and favoring all kinds of abuse of the most vulnerable actors, the women who work as prostitutes and who are far away from their own country, with no social or other references. A third aspect concerns the fact that illegal immigration is a situation in which both promoters and victims (the immigrants and the exploited) share a fear of the state and the security forces. Finally, there is the fact that, due to its illegal nature, prostitution combined with pimping almost always operates in a climate of fear (even when trafficking is not involved) that is well justified by the very real likelihood of violent reprisals. As the studies reveal, this culture of fear involves explicit threats to women's physical integrity and that of their family members, including those in their home country. But it also refers to the tacit climate of reprisals and violence which pervades the world of pimping, deterring any kind of denunciation of cases of sexual exploitation, not only by the women involved in trafficking situations but also by other women and other actors who are aware of, or strongly suspect, these facts.

Bearing in mind these complex networks and precarious contexts, the original reasons that led women into trafficking cannot be ignored. Nor should we neglect the women's desires and expectations of finding a more stable and secure life in the host country, which may still appear acceptable after the risks have been considered. Neglecting these factors leads to the risk of producing a definition of trafficking that establishes hierarchies informed by moral values, which ultimately lead to the setting up of legal and/or practical barriers between women who deserve more help, women who deserve a relative amount of help, and women who do not deserve any kind of help at all (Anderson and Davidson 2002, p. 17).

Migrant Women in Prostitution: the Specificities of the Brazilian Women in the Portuguese Case

The previous theoretical discussion on the definition of trafficking and exploitation is particularly interesting in the 
Portuguese case. According to the result of the studies on which this article is based and to official data (OTSH 2010), Brazilian women are among the main nationalities of victims of sexual trafficking in Portugal. ${ }^{14}$ These women are, on the whole, from a disadvantaged economic and social background and migrate with the expectation of being able to improve their lives. However, various studies also indicate that Brazilian women are those who are more common in prostitution in Portugal. This is evident from the study carried out by Ribeiro et al. (2005) on prostitution in clubs, which concludes that women who work as prostitutes in clubs and hostess bars come primarily from Latin America, specifically from Brazil (62\%) and Colombia (8\%). This also appears to be the opinion of certain civil society organizations I interviewed, who work directly with female prostitutes. This view is related to the dissemination of a stereotype of the Brazilian woman associated with pleasure and sensuality (Téchio 2006), to which may be added the ease of communication due to language similarities, which increases their demand in the sex industry. The number of Brazilian women working as prostitutes leads to a process in which the stigma of prostitution is "passed on" to other immigrants of the same nationality. The "Mães de Bragança"15 movement has contributed to this, and the high-profile media coverage of this case encouraged a moralist conception that has been used to demonize Brazilian women in Portugal. This is a key question in the identification of trafficking situations and the social construction of "good victims," as opposed to "bad victims", as we discussed in the last section. Considering that the presence of these women in prostitution is not regulated and, rather, tends to be framed within the lens of sexual trafficking, this has consequences in the application of the law.

Firstly, the fact that prostitution involving Brazilian women is overwhelmingly viewed as voluntary "migrant work" may mean that situations involving exploitation and trafficking are ignored. According to the experiences of many of the judges and police officers interviewed, the majority of Brazilian women who ended up involved in trafficking, as defined in law, initially gave their consent to work in prostitution as a migratory strategy but later found themselves in situations in which they were heavily exploited. Extreme cases of deception - in which the woman did not know she would be forced to work as a prostitute

\footnotetext{
${ }^{14}$ Although immigration routes do not necessarily have to coincide with the trafficking routes, there is a tendency for the recruitment of victims for a particular country to be related to the immigrant communities which have already established themselves there. Brazil is one of the main countries of immigration to Portugal mainly because Portuguese is the language spoken in both countries.

15 "Mothers of Bragança" was a movement organized in 2003 by a group of women from the city of Bragança, in northeast Portugal, with the aim of driving out of town those Brazilian women working in clubs or as prostitutes.
}

or in any other activity of a sexual nature-involve primarily women of other nationalities:

[...] We look at a Brazilian citizen who is operating freely in a particular place and maybe we don't immediately tend to see her as a victim of trafficking. That is not to say that she might not be, that issues concerning her origins before coming here might not make her a victim of trafficking. But the tendency is not to consider this. [...] So the women are immediately taken to begin deportation procedures and the case is closed. This is a situation that clearly has to be corrected. On the other hand, what happens with others from Eastern Europe is that we immediately look at them differently, because these are situations that clearly represent potential cases of trafficking. Not just pimping, not just illegal immigration, but potential trafficking situations. (Interview with police officer 2009).

But in this analysis, we should bear in mind that it was through violent cases involving women from Eastern Europe that Portugal woke up to the reality of this kind of trafficking. Our data suggests that sexual trafficking in Portugal, including the majority of cases involving the trafficking of Brazilian women, is nowadays practiced essentially by unorganized, amateurish groups; Eastern European organized criminal groups are less prevalent. Indeed, in these informal groups, it is not unusual for the recruiters to be people who have great credibility in the eyes of their victims, since they are friends, family members, colleagues, etc. (see also, Leal and Leal 2007; Aghatise 2004; Aronowitz 2001). These data suggest that while it is true that there is increasingly more national legislation following the multiple international conventions and regulations, it is also true that we can question if those norms are adapted to the changes in the reality of human trafficking in Europe, with multiple nationalities and dynamics merging, or if they are still focused on Eastern Europe and organized crime:

(...) Most of these Conventions are very much directed towards and focused on Eastern Europe. Nowadays we know that there are still organized groups associated with women who come from Eastern Europe, but the greater part of the "market" is ensured by Brazilian women, and this is a very specific reality that tends to evade the nature of the Conventions. (Interview with magistrate 2008)

As Kempadoo and Doezema (1998) warn us, terms and imagery of trafficking may not only misrepresent what goes on in the "Global South" but also what goes on in Europe. The final and imminent risk is that of a substantial discrimination against foreign women working in prostitution without coercion, if they see themselves stripped of their rights as immigrants and as workers. It is these women, rather than 
those of Portuguese nationality, who upon an inspection raid of a hostess bar, ${ }^{16}$ for example, are jailed by the police and deported to their country of origin. As mentioned earlier, this is a real risk because many of these women see their tourist visas expire but cannot apply for legal immigrant status, as they are unable to provide a place of work or a contract. The truth is that in Portugal, as in many European countries, the status of trafficking victim is one of the few means of attaining residence rights. ${ }^{17}$ So the question is does a migrant woman have to be vulnerable to earn the legal protection of the host state, in this case, Portugal (Alpes 2008, p. 34)? This view is particularly important when the aforementioned Southern perspective is introduced into the analysis, forcing us to take into account the context, the origin, and strategies of women who, due to various factors (economic, cultural, the consequences of war, etc.), decide to emigrate to work in the sex industry.

These risks reflect one of the most obvious shortcomings in the law. The law turns citizens into subjects of rights and responsibilities, standardizing them to the extent to which all are equal before the law, and it naturalizes them on the premise that all were equal previous to the law (Kapur 2006, p. 104). Some of these women are migrant workers and not sex slaves; they want security but do not want to be saved (Kempadoo 2005), so they need other policies to protect their autonomy and rational choice rather than policies directed at sexual trafficking victims.

\section{Final Reflections}

As we have seen, in Portugal, prostitution has not been a crime per se (since 1982) but likewise has not been subject to regulation as an economic occupation. This legal inconsistency is further complicated by the lack of specific policies addressing the working and living conditions of sex workers. A lack of reflection and a significant level of disagreement on the part of the feminist movement have partly contributed to this policy deficit. Institutional feminism, which brought the question of sexual trafficking into

\footnotetext{
${ }^{16}$ Among the legal instruments, police officers have to regulate social and sexual behaviors; we find regulation of car traffic, closing down of sex clubs or venues known for sex work, and the identification of women who are working as prostitutes on the street.

${ }^{17}$ According to the Immigration Law-Law 23/07 of 4th July 2007in Portugal, residence permits for victims of trafficking are issued if the person concerned cooperates with the authorities. Once the case is closed and the person decides to stay in Portugal, another residence permit is issued based on the general Portuguese provisions for residence permits, which entitles the person to the same rights as a Portuguese citizen including social security system, etc. When the victim does not want to cooperate with the authorities, a staying permit on special grounds can be issued, i.e., if the person concerned is at risk or if the family of the person is at risk and protection cannot be ensured.
}

the public arena without due and careful reflection about prostitution, is also to blame. The growing concern about sex trafficking has resulted in a new set of legislative measures that ultimately end up creating a huge contrast between the attention granted by the state to the trafficking issue and the efforts made to improve other groups within the commercial economy for sex, e.g., the social, economical, and working conditions for Portuguese sex workers (Oliveira 2004). Legislation tends to be more directed towards the criminal pursuit of trafficking without taking into account other fundamental legislative measures, such as the reinforcement of immigrant or labor rights, whether for national or other citizens. To this effect, with police actions that seek to dismantle trafficking networks, what happens all too often is that immigrant women who work as prostitutes, but do not have a work visa, end up being detained and deported. This is paradigmatic, as we have seen, for women whose right to residency is tied up to their status as victims and willingness to cooperate with the authorities. The existence of foreign sex workers within society is not properly recognized in Portugal's, as in other European countries', legal framework; hence, their legality is limited by the tourist visa, the ability of the state to identify trafficking victims, and the level of tolerance of their social surroundings. In this sense, the law seems, "in practice," to promote their irregularity and social marginalization. At the core of this inconsistency seems to be the question of whether prostitution should be regulated as work or as exploitation and what sorts of choices are tolerated, stigmatized, or punished by legal authorities. The hypothesis that stems from the reflection in this paper is that the regulation, even if unintentional, of prostitution through the legal framework of sex trafficking does not only not support dignified living conditions for female prostitutes but it can also hamper the identification of victims of trafficking.

To be effective, policies against trafficking must take into consideration the claims of the women in prostitution. An in-depth debate is necessary on the subject of consent. The concept of consent and its role in law have drawn the attention of feminists who, surprisingly or not, have disagreed about the extent to which the concept has the potential to empower or disempower women (Hunter and Cowan 2007). For some authors, the legal recognition of women's consensual capacity regarding prostitution or being trafficked for the purpose of sexual exploitation may ignore the pragmatic constraints that harsh reality unleashes upon women's consensual freedom and exercise of rational choice (Drakopoulou 2007, p. 11). Others see it as conferring upon women the power of agency and the status of rational actor, deconstructing women as submissive or victimized (Sullivan 2004). Sexual slavery and the forms of extreme exploitation to which female prostitutes may be exposed undoubtedly represent situations of suffering. Yet voluntary consent must also be 
studied. The wretchedness and poverty underlying such decisions should be confronted. Voluntary acts usually occur on an individual level but are the expression of collective acts of social injustice. Such injustice makes society itself culpable; in other words, a capitalist society produces the very conditions that contribute to these women's voluntary acts. In summary, acknowledging the power relationships in the neoliberal context of the global sex industry (Scoular and Sanders 2010), it is crucial to consider the dynamics that migrant sex workers display between repression and resistance (Kapur 2001, p. 857).

In addition, in several countries, the treatment of women who are victims of trafficking is often influenced by moral concepts, whether within the context of normative provisions or their application. Because of the strong social stigma attached to female prostitutes, their civil and human rights are frequently violated (Anderson and Davidson 2002 , p. 40). Very few countries offer effective legal protection to women who work as prostitutes. Moreover, in the case of Portugal, as previously stated, the stereotypes and preconceptions relating to prostitution and immigrant women of particular nationalities may mean that even the trafficking law is not enforced. This is particularly true in the case of Brazilian women who are identified, in Portugal, as the main nationality in the sex industry and also among victims of sexual trafficking. There seems to be a paradox in the responses of the people who were interviewed: these Brazilian women, as prostitutes, are those who are most frequently "detained" in police raids, owing to their illegal status, and, as victims, are the least protected because they are not easily perceived as victims of trafficking. Therefore, it makes sense to reinstate the fears of some authors that prostitution and trafficking have entered the political discourse of many Western countries, controversially revealing the presence of migrant women (Engle 2004; Sassen 2003; Gaspard 1998).

This specificity that Portugal takes on in the European sex trafficking scenario is also useful to better understand the legal challenges that occur when international conventions and legal definitions are "translated" into local social and political contexts. Some judges and public prosecutors seem to understand that the Portuguese legal system and immigration policies are not adequately adjusted to the increasingly complex realities of global migration, or of trafficking. This is a presupposition that can be similarly transposed to other countries. When speaking about trafficked women's rights, it is necessary to understand that these women are not the same in all countries and that they come from culturally and socially diverse regions. These important social and cultural distinctions must be recognized (e.g., Santos 2009; Kapur 2006). While it is fundamental that gender should not be forgotten in the issue of sex trafficking (or migration), neither should we resort to an essentialism which views women as a homogenous category, not the least because when causes are homogenized, the same can easily happen to solutions. This "South critique" shows us that it is very problematic that the international debates and policies on prostitution and trafficking are imported from contextless international bodies.

To conclude, I believe it is fundamental that the law and, basically, any policy designed to combat the trafficking of women for the purposes of sexual exploitation should clearly aim for transformational measures strengthening women's individual and collective awareness. Such efforts must fight the various forms of oppression which seek to subordinate them while avoiding reducing women to the category of passive victims or allowing them to be stigmatized or excluded. We argue that a progressive attitude is one which strengthens these women's collective awareness, not present in the interviews with sex workers, by constructing their citizenship, and allows a revisiting of the prostitution and sex trafficking regulations marked by a greater sense of social justice (Scoular and O' Neill 2007). This is the greatest challenge that sex trafficking presents to the legal system.

\section{References}

Aghatise, E. (2004). Trafficking for prostitution in Italy: possible effects of government proposals for legalization of brothels. Violence against women, 10, 1126-1155.

Agustín, L. (2007). Sex at the margins: Migration, labour markets and the rescue industry. London: Zed Books.

Alpes, M. J. (2008). The traffic in voices: contrasting experiences of migrant women in prostitution with the paradigm of "human trafficking". Human Security Journal, 6, 34-45.

Anderson, B., \& Davidson, J. (2002). Trafficking - a demand led problem. Sweden: Save The Children.

Aronowitz, A. A. (2001). Smuggling and trafficking in human beings: the phenomenon, the markets that drive it and the organisations that promote it. European Journal on Criminal Policy and Research, 9, 163-195.

Barry, K. (1995). The prostitution of sexuality. New York: New York University Press.

Bastos, S. P. (1997). O Estado Novo e os seus vadios. Contribuições para o estudo das identidades marginais e da sua repressão. Lisboa: Publicações Dom Quixote.

Doezema, J. (2005). Now you see her, now you don't: sex workers at the UN Trafficking Protocol negotiations. Social \& Legal Studies, $1,61-89$.

Drakopoulou, M. (2007). Feminism and consent: A genealogical inquiry. In R. Hunter \& S. Cowan (Eds.), Choice and consent: Feminist engagements with law and subjectivity (pp. 9-38). London: Routledge.

Duarte, M. (2004). Participation through justice: a (new) way of protest. Il Dubbio, 2, 30-43.

Ehrenreich, B., \& Hochschild, A. R. (2002). Global woman: Nannies, maids and sex workers in the new economy. London: Granta Books.

Engle, L. B. (2004). The world in motion: Short essays in migration and gender. IOM. 
uaspard, r. (19yð). Invisıveıs, diabolızadas, instrumentalızadas: riguras de mulheres migrantes e das suas filhas na Europa. Revista Crítica de Ciências Sociais, 50, 83-101.

Guinote, P., \& Oliveira, R. B. (1989). Prostituição, boémia e galanteria no quotidiano da cidade. In A. Reis (Ed.), Portugal Contemporâneo (pp. 339-382). Lisboa: Publicações Alfa.

Hernes, H. (1987). Welfare state and woman power: Essays in state feminism. Oslo: Norwegian University Press.

Hunter, R., \& Cowan, S. (Eds.). (2007). Choice and consent: Feminist engagements with law and subjectivity. London: Routledge.

Jeffreys, S. (1999). Globalizing sexual exploitation: Sex tourism and the traffic in women. Leisure studies, 18, 179-196.

Kapur, R. (2001). Post-colonial economies of desire: legal representations of the sexual subaltern. Denver University Law Review, 78 (4), 855-85.

Kapur, R. (2006). Revisioning the role of law in women's human rights struggles. In S. Meckled-García \& B. Çali (Eds.), The legalization of human rights: multidisciplinary perspectives on human rights and human rights law (pp. 93-107). London: Routledge.

Kempadoo, K. (2005). From moral panic to global justice: Changing perspectives on trafficking. In K. Kempadoo (Ed.), Trafficking and prostitution reconsidered: New perspectives on migration, sex work, and human rights (pp. 3-24). Boulder: Paradigm Publishers.

Kempadoo, K., \& Doezema, J. (Eds.). (1998). Global sex workers: Rights, resistance, and eedefinition. New York: Routledge.

Leal, M. L., \& Leal, M. F. (2007). Enfrentamento do Tráfico de Pessoas: uma questão possível? Política Nacional de Enfrentamento ao Tráfico de Pessoas, 1, 28-32.

Leal, M. L., Duarte, M., \& Teresi, V. (Eds.). (2011). Mulheres brasileiras na conexão ibérica: um estudo comparado entre migração irregular e tráfico. Brasília: CNQP.

Lopes, A. (2001). Sex workers of the world unite. Feminist Review, 67, 151-153.

McBride, D. M., \& Mazur, A. (Eds.). (2008). Comparative state feminism. Thousand Oaks: Sage.

Oliveira, A. (2004). As vendedoras de ilusões: Estudo sobre a prostituição, alterne e striptease. Lisboa: Editorial Notícias.

OTSH. (2010). Trafficking in human beings: National report. Lisbon: DGAI.

Outshoorn, J. (2005). The political Debates on Prostitution and Trafficking of Women. Social Politics, 12(1), 141-155.

Ribeiro, M., Silva, M. C., Ribeiro, F. B., \& Sacramento, O. (2005). Prostituição abrigada em clubes (zonas fronteiriças do Minho e Trás-os-Montes). Lisboa: CIDM (Colecção Estudos de Género).

Roberts, N. (1996). A prostituição através dos tempos na sociedade ocidental. Lisboa: Editorial Presença.

Santos, B. S. (1995). Toward a new common sense. London: Routledge. santos, B. S. (LUUY). Iowara a multicuitural conception or numan rights. In F. G. Isa \& K. Feyter (Eds.), International human rights law in a global context (pp. 97-121). Bilbao: University of Deusto. Toward a multicultural conception of human rights.

Santos, A. C. (2010). Portugal. In Sasha Roseneil (Ed.), Changing cultural discourses about intimate life: the demands and actions of women's movements and other movements for gender and sexual equality and change. FEMCIT Working Paper 2, available at http://www.femcit.org/files/WP6_WorkingpaperNo2.

Santos, B. S., Duarte, M., \& Gomes, C. (2005). The sexual trafficking of women: Representations of illegality and victimisation. RCCS Annual Review, 2, 1-25.

Santos, B. S., Duarte, M., Gomes, C., \& Baganha, M. (2008). Trafficking in women for the purpose of sexual exploitation in Portugal. CIG (Colecção Estudos de Género): Porto.

Santos, B. S., Duarte, M., \& Gomes, C. (2010). The sexual trafficking of women: Representations of illegality and victimisation. RCCS Annual Review, 2, 1-25.

Sassen, S. (2003). Global cities and survival circuits. In B. Ehrenreich \& A. R. Hochschild (Eds.), Global woman: Nannies, maids and sex workers in the new economy (pp. 254-274). London: Granta Books.

Scoular, J. (2004). The 'subject' of prostitution: interpreting the discursive, symbolic and material position of sex/work in feminist theory. Feminist Theory, 5(3), 343-355.

Scoular, J., \& O' Neill, M. (2007). Regulating prostitution: social inclusion, responsibilization and the politics of prostitution reform. British Journal of Criminology, 47, 764-778.

Scoular, J., \& Sanders, T. (2010). Regulating sex/work: From crime control to neo-liberalism? London: Wiley.

Skilbrei, M., \& Tveit, M. (2008). Defining trafficking through empirical work: blurred boundaries and their consequences. Gender Technology and Development, 12(1), 9-30.

Sullivan, B. (2003). Feminism and new international law. International Feminist Journal of Politics, 1, 67-91.

Sullivan, B. (2004). Prostitution and consent: Beyond the liberal dichotomy of "free or forced". In M. Cowling \& P. Reyonolds (Eds.), Making sense of sexual consent (pp. 127-140). Aldershot: Ashgate.

Tavares, M. (2011). Feminismos em Portugal: Percursos e desafios. Lisboa: Texto.

Téchio, K. (2006). Conhecimentos de Alterne: A outra diáspora das imigrantes brasileiras. Socius Working Papers, 2, 1-22.

Valiente, C. (2007). Are gender equality institutions the policy allies of the feminist movement? A contingent 'yes' in the Spanish central state. South European Society and Politics, 3, 315-334.

Vaz Patto, P. (2007). O crime de tráfico de pessoas no Código Penal revisto. Análise de algumas questões. Jornadas sobre a Revisão do Código Penal - 27 e 28 de Setembro de 2007, Lisboa: CEJ. 